1 Impacts of Thermal and Smouldering Remediation on Plant Growth and Soil

\title{
2 Ecology
}

3 Andrew Pape, Christine Switzer, Neil McCosh, and Charles W. Knapp*

4 Department of Civil and Environmental Engineering, University of Strathclyde, Scotland, UK

5 andrew.pape@strath.ac.uk; christine.switzer@strath.ac.uk; neil.mccosh@strath.ac.uk;

$6 \quad$ charles.knapp@strath.ac.uk

7

$8 *$ Correspondence: charles.knapp@strath.ac.uk

9

Department of Civil and Environmental Engineering,

10

University of Strathclyde, $5^{\text {th }}$ Floor, James Weir Building

11

75 Montrose Street, Glasgow, Scotland, UK G1 1XJ

12

Phone: +44 (0) 1415483351

13

14

15 Full version: doi: 10.1016/i.geoderma.2014.12.004

16 Geoderma (2015) 243/244: 1-9

17 http://authors.elsevier.com/a/1QD5r3p6n-QLd 


\section{Introduction}

Soil contamination remains a global problem. Europe faces an estimated 342,000 sites of known contamination and a further 2.5 million potentially contaminated sites (van Liederkerke et al., 2014). A great deal of effort has gone into developing remediation processes to remove or reduce the impact of these contaminants in the environment. For organic pollutants such as oils, tars, and polycyclic aromatic hydrocarbons (PAHs), a range of techniques has been developed using heat treatment or combustion processes to volatilise and extract, or destroy, these contaminants. Typical operating ranges vary from $100^{\circ} \mathrm{C}$ for many vapour extraction methodologies (Heron et al., 2005; Buettner and Daily, 1995), to in excess of $1000^{\circ} \mathrm{C}$ during ex-situ incineration of heavy oils and tars (Anthony and Wang, 2006). Smouldering remediation exposes soils to temperatures of $600-1100^{\circ} \mathrm{C}$ or more (Switzer et al., 2009; Pironi et al., 2011; Switzer et al., 2014). Optimised treatment regimes can significantly reduce the contaminant load of the soil, sometimes to safe levels where re-use can be considered; however, the effects of treatment conditions on soil quality must be understood in order to support re-development after remediation.

Post-remediation effects are particularly important if the soils are to support plant growth for phytoremediation, biomass crop production, habitat restoration, or urban green space. The effects of heating on soil depend on treatment temperatures and the duration of exposure. Even the lower temperatures $\left(\sim 100^{\circ} \mathrm{C}\right)$ utilised in remediation will impact soil biota-killing plant propagules, macro fauna, and microorganisms (Certini, 2005). As treatment temperatures increase, other negative impacts occur, such as charring and subsequent loss of organic matter (Certini, 2005) and atmospheric losses of nitrogen (Glass et al., 2008; Gray \& Dighton, 2006). Losses of organic matter and nitrogen will be almost complete for any treatments above $500^{\circ} \mathrm{C}$ (Glass et al., 2008; Gray \& Dighton, 2006), at which point clay minerals breakdown and aggregate, physically altering the soil (Ulery et al., 1996; Terefe et al., 2008; Ketterings et al., 2000). Physical changes to clay minerals and loss of organic matter severely reduce soil's ability to retain valuable nutrients (Kang and Sajjapongse, 1980). High temperatures also affect the biological availability of many macro- 
nutrients such as phosphorus, potassium and calcium by altering geochemistry (Kang and Sajjapongse, 1980; Galang et al., 2010). At very high temperatures (e.g., >1000 $)$, less volatile nutrients may become lost to the atmosphere, including phosphorus (Galang et al., 2010). Compiled literature evidence suggests alterations to chemical conditions depend on remediation temperature.

While many previous experiments have focused on relatively lower temperatures and discrete target temperatures, few have examined the full-range of temperatures utilised by remediation technologies. Even less frequently have chemical conditions been compared to multiple biological metrics simultaneously. At low heating temperatures $\left(60-350^{\circ} \mathrm{C}\right)$, complicated relationships exist between heating temperature and plant growth (Cébron, et al., 2009; 2011). Combining the results of a number of studies, Johnson (1919) observed that heating in this range could unpredictably have both positive and negative effects on growth depending on soil and plant type. At higher temperatures $\left(>400^{\circ} \mathrm{C}\right)$, results seem more consistent. For instance, Kang and Sajjapongse (1980) observed reduced biomass in rice plants grown in soil heated to $500^{\circ} \mathrm{C}$ compared to those heated to $200^{\circ} \mathrm{C}$ or less. Roh et al. (2000), studying the thermal desorption of mercury, found greater plant growth in soil treated at $350^{\circ} \mathrm{C}$ compared to $600^{\circ} \mathrm{C}$, despite higher residual toxin levels. Given the range of temperatures now utilised during thermal and smouldering remediation (ambient to over $1000^{\circ} \mathrm{C}$ ), evaluation of the effects of soil heating on plant growth over this full range is important to estimate the effects of specific remediation techniques. In addition to impacts on plants, soil heating can have significant effect on the soils' ability to sustain microbial communities, with consequential impacts on nutrient cycling, organic decomposition, and, in terms of soils with remaining contamination, bio-polishing of residual contaminants (Cébron, et al., 2009, 2011; Thion, et al., 2012). Successful re-colonisation by microorganisms and plants is essential to sustainable ecosystem recovery. Re-colonisation depends on many factors, but the availability of food (carbon) and nutrients are two key factors. For example, Bárcenas-Moreno and Bååth (2009) observed reduced microbial biomass after 21 days of incubation when carbon levels 
had significantly been reduced by heating to $400-500^{\circ} \mathrm{C}$. Higher temperatures are even more likely to remove carbon and nutrients, and as a result, microbial re-colonisation of these soils becomes severely inhibited. The extent to which micro-organisms can re-colonise soils, in terms of keypopulation levels and functional roles, are important in predicting whether long-term viable soil ecosystems are possible without continuous nutritional inputs.

This paper examines how full-range of soil remediation technologies impact Trifolim pratense (red clover) and Festuca rubra (red fescue), two representative proxies for the effects of thermal and smouldering remediation processes on plants. The red clover was selected for its ability to create rapid vegetative cover, fix atmospheric nitrogen through associations with symbiotic microorganisms, and enhance succession on lithoseric soils (Li and Daniels, 1992; Jefferies et al., 1981). Fescue is a commonly used grass for soil-erosion control and establishing plant growth on bare ground. Changes to soil physical and chemical properties are simultaneously quantified to determine changes to soil characteristics after thermal $\left(105-1000^{\circ} \mathrm{C}\right)$ and smoulder treatments. Microbial community recovery and enzyme activity are examined to establish the soils' capabilities to effectively cycle nutrients. These analyses identify, among the combinations of high temperature treatment and soil types, the ecological impacts to better inform post-treatment interventions to create an effective growing media for the desired land use.

\section{Materials and Methods}

\subsection{Soil Samples and Treatments}

We selected two topsoils for this study: an acidic loam (Soil 1) from northeast Scotland, and a commercially available horticultural soil (Soil 2 ) with a neutral $\mathrm{pH}$. While organic contaminants could contribute to soil structure (Monserie et al., 2009), pristine soils were selected for quasi-baseline purposes. All soils were air-dried and sieved to below $2 \mathrm{~mm}$; soils were then oven dried at $105^{\circ} \mathrm{C}$ for three days to remove moisture before being heat-treated at $250^{\circ} \mathrm{C}, 500^{\circ} \mathrm{C}, 750^{\circ} \mathrm{C}$ and $1000^{\circ} \mathrm{C}$. 
Basically, 500g-portions of oven dried soil were spread out in a large crucible, around $4 \mathrm{~cm}$ deep, heated in a muffle furnace (Nabotherm P330, Lilienthal, Germany) and then held at temperature for one hour; 15-20 portions were bulked together for each soil-temperature treatment. Air-dried soils, without any further heating, represented experimental controls.

Additional portions of each soil type were artificially contaminated with coal $\operatorname{tar}(80 \mathrm{~g} / \mathrm{kg})$ and treated via smouldering remediation (SM) (Pironi et al., 2009) to evaluate its related effects. Based on Switzer et al. (2009), a heating element and air diffuser were emplaced in around $5 \mathrm{~cm}$ of clean sand at the bottom of a 3-litre quartz column. The column was filled with contaminated soil until $10 \mathrm{~cm}$ of the beaker remained, and another layer of clean sand. A central line of thermocouples was used to monitor smoulder progression. The smoulder process started by heating soils to $300^{\circ} \mathrm{C}$, at which point the air flow commenced and the heater was switched off. Smouldering proceeded until smoke production ceased and temperatures declined, at which time airflow was stopped.

\subsection{Soil Analyses}

Further details of the physical and chemical measurements of soils can be found in Pape, et al. (in review). Soil pH (BS, 2005) and electrical conductivity (BS, 1995c) were recorded using a Multi 7 Mettler-Toledo meter (Columbus, OH, USA) after a two hour extraction in 1:5 soil:water mix. Total organic content was measured by dry ashing at $550^{\circ} \mathrm{C}$ for five hours (BS, 2000). Total nitrogen (BS, 2001) was measured by quantifying $\mathrm{NO}_{x}$ production during combustion using an Apollo 9000 TOC/TN analyser (Teldayne Tekmar, Mason, $\mathrm{OH}, \mathrm{USA})$. Inorganic nitrogen species $\left(\mathrm{NH}_{4}{ }^{+}, \mathrm{NO}_{3}{ }^{-}\right.$and $\mathrm{NO}_{2}{ }^{-}$) were measured colorimetrically: an indophenol blue method for $\mathrm{NH}_{4}^{+}$; and a sulfanilic acid method for $\mathrm{NO}_{2}^{-}$with a hydrazine reduction step for $\mathrm{NO}_{3}^{-}$(ADAS, 1985; Bundy and Meisinger, 1994; Shand et al., 2008). In this study, the only form of inorganic nitrogen present in measurable quantities was ammonium. Available phosphate was measured after an Olsen bicarbonate extraction using molybdate/ascorbic acid colorimetry (ADAS, 1985). Cation exchange capacity (CEC) and exchangeable bases (ADAS, 1985) were measured by sequential leaching with ammonium 
acetate and potassium chloride; flame atomic absorption (Perkin Elmer AAnalyst 100, Waltham, MA, USA) determined quantity of bases, and CEC was determined colorimetrically (Bundy and Meisinger, 1994). Levels of bio-available copper and zinc were measured by extraction in ammonium-EDTA (ADAS, 1985) and ICP-OES analysis (Thermo Scientific, Hemel Hempstead, UK). Additionally, proportions of clay, silt and sand were measured using wet sieving and sedimentation (BS, 2009) after dispersion in a sodium carbonate/sodium hexametaphosphate solution.

\subsection{Plant Growth Trials}

Each soil and temperature treatment was further divided by different microbial amendments. Soils were initially wetted to $25 \% \mathrm{v} / \mathrm{m}$ with either sterile de-ionised water controls or microbially amended (MA) with $0.1 \% \mathrm{~m} / \mathrm{m}$ of commercial mycorrhizal inoculant and $25 \% \mathrm{v} / \mathrm{m}$ of aerated compost tea (ACT). The ACT comprised of compost $(500 \mathrm{~mL})$ in $15 \mathrm{~L}$ of sterile, deionised water, and juice of one orange; this mixture was aerated for $24 \mathrm{hr}$ to encourage microbial growth. The soils were then incubated at $27^{\circ} \mathrm{C}$ for seven days before being portioned into $200 \mathrm{ml}$ pots. Replicates of $3-$ 4 pots in each treatment were planted with nine red clover (Trifolium pratense) or nine red fescue (Festuca rubra) seeds, with additional samples left as unplanted controls. All pots were watered using a wick system to maintain constant moisture content (BS, 2011) and grown in a growth chamber at $27 \pm 2^{\circ} \mathrm{C}$ with 16 hours of light per day. One week after planting, the plants were thinned to two per pot, and after a further six weeks, they were harvested and the soils stored refrigerated $\left(4^{\circ} \mathrm{C}\right)$ for analysis.

After harvest, the plants were dried at $70^{\circ} \mathrm{C}$ and analysed for shoot and root extension and dry mass of the roots, shoots, and leaves. In addition, frozen sub-samples of the leaves were analysed for chlorophyll content. Chlorophyll was extracted by heating a leaf sample (20-100mg wet weight) in $10 \mathrm{ml}$ of di-methyl sulfoxide at $70^{\circ} \mathrm{C}$ for six hours (Hiscox and Israelstam, 1979) and analysed colorimetrically according to the equations of Arnon (1949). For clover, the numbers of symbiotic root nodules were also recorded for each plant. 
144 To understand the dynamics of the microbial populations, their activities and gene abundances were

145 quantified at the end of the six-week experimental period. To quantify gene abundance in the soil, $1460.25 \mathrm{~g}$ samples were extracted using a MoBio (Carlsbad, CA, USA) PowerSoil DNA isolation kit and a 147 cell disruptor (FastPrep24, MP Biomedicals; Solon, OH, USA). Abundance of "total bacteria" was 148 quantified by qPCR using a BioRad (Hercules, CA, USA) sso-Advanced enzyme system analysing 149 portions of the $16 \mathrm{~S}$ ribosomal RNA gene (Muyzer et al., 1993). In addition, bacteria related to nitrogen cycling were quantified using the same system by targeting specific functional genes, including: nifH (Poly et al., 2001) for nitrogen fixers, nirS (Kandeler et al., 2006) and nirK (Henry et al., 2004) for nitrifiers (nitrite reduction), and amoA (Rotthauwe et al., 1997) for ammonia oxidising bacteria. These functional genes were normalised to $16 \mathrm{~S}$ rRNA to represent relative abundances of total bacteria. See Table 1 for list of specific primers and qPCR operating conditions. Quality control included purified plasmid standards (Smith et al., 2004; Graham et al., 2010), template-free blanks and post-analytical melt curves to verify PCR reaction efficiencies and check for the presence of PCR artefacts.

Several extra-cellular enzyme activities were monitored as indicators of microbial activity in the soil. Monophosphoesterase (acid and alkali) and $\beta$-glucosidase were analysed using the nitrophenol conjugate system (Tabatabai, 1994; Eivazi and Tabatabai, 1988; Tabatabai and Bremner, 1969); nitrophenol was produced as enzyme activity removed functional groups (either phosphate or glucose), and quantified colorimetrically at $400 \mathrm{~nm}$ upon the addition of a strong alkali. Ammonia oxidase activity (Jarvis et al. 2009) was measured by observing the production of nitrite, by sulfanilic acid colorimetry, in the presence of ammonium sulphate and sodium chlorate, a metabolic inhibitor to prevent the oxidation of nitrite to nitrate. 
Statistical analyses were performed using SPSS (v. 20) software. Data distributions were tested using the Kolmogorov-Smirnov test for single populations. Treatment comparisons were performed either by $t$-tests or one-way ANOVA. Due to statistical similarity among irrigation treatments, the microbial treatments of each soil were combined within each heat treatment and compared by one-way ANOVAs followed by post-hoc $t$-tests (see supplemental information). Level of significance was predetermined to be $\alpha=0.05$.

\section{Results and Discussion}

\subsection{Physical and Chemical Changes to Soil Properties}

When subjected to heating, both soil types exhibited similar changes to their particle size distribution. At temperatures of $250^{\circ} \mathrm{C}$ and above, organic matter is lost through pyrolysis and oxidation with only a small fraction of the original content remaining at $750^{\circ} \mathrm{C}$ (Table 2). At temperatures above $500^{\circ} \mathrm{C}$, the proportion of clay-sized particles declined (Table 3) through aggregation and disintegration (Ulery et al. 1996; Terefe et al., 2008; Ketterings et al., 2000). Together, these losses resulted in a significant reduction in the CEC and the soils' ability to retain nutrients and water. Additionally, changes in the structure and cohesion of the soil seemed to occurred, with reduced aggregate formation qualitatively observed in soils heated above $500^{\circ} \mathrm{C}$. While not quantified in these experiments, this would be important to monitor in field investigations, as it impacts soil stability and cohesion.

Macro- $(\mathrm{N}, \mathrm{K}, \mathrm{P}, \mathrm{Ca}, \mathrm{Mg})$ and micro- $(\mathrm{Cu}, \mathrm{Zn})$ nutrient levels in the soils were affected by heating (Table 2). Some organic nitrogen mineralised to ammonium when heated to $250^{\circ} \mathrm{C}$ in Soil 1 , and $105^{\circ} \mathrm{C}-250^{\circ} \mathrm{C}$ in Soil 2 . Above $500^{\circ} \mathrm{C}$, the levels of both inorganic and total nitrogen declined due to volatilisation (Glass et al., 2008). Most other nutrient concentrations showed a negative relationship with heating temperature. Leachable copper, zinc and phosphate declined in both soils; whereas, magnesium and calcium levels were reduced in Soil 1 , and potassium in Soil 2 . By $1000^{\circ} \mathrm{C}$, the 
bioavailability of most nutrients declined in both soils, which would become a concern for plant growth. Additionally, limited levels of copper and zinc could have impacted microbial enzyme systems (discussed later).

In terms of other chemical properties, the results became more variable and dependent on soil type. Soil 2 showed variable levels of exchangeable calcium across heating treatments (Table 2). Both soils increased in pH as observed in other studies (Granged et al., 2011; Ketterings et al., 2000), but in varying degrees. For Soil $1, \mathrm{pH}$ reached 7.3 at $1000^{\circ} \mathrm{C}$, likely due to destruction of organic acids, which would not be anticipated as a problem for restoration after treatment. In Soil 2, the pH reached 11.3 in samples heated at $\geq 750^{\circ} \mathrm{C}$, which would severely affect subsequent biological activity. This high $\mathrm{pH}$ was likely due to the calcination of $\mathrm{CaCO}_{3}$ to highly soluble and alkaline $\mathrm{CaO}$ at these temperatures (Giovannini et al., 1990), as evidenced by the high electrical conductivity and $\mathrm{Ca}^{2+}$ concentrations at these temperatures.

\subsection{Plant Growth Trials}

Red clover and red fescue were grown in each of the soil treatments (air-dried controls, $105-1000^{\circ} \mathrm{C}$ and smouldered) to quantify the effects of soil changes on plant growth. Based on initial treatment comparisons (t-tests), treatment temperature was the main driver of treatment variability; as such, microbial treatments of each soil were combined within each heat treatment and compared by oneway ANOVA. Plant biometrics showed a negative trend between treatment temperature and plant growth for both species in both soils (Fig 1). Biomass production appeared to be a more sensitive metric than extension, but both results showed similar patterns. Heat treatments $\geq 250^{\circ} \mathrm{C}$ resulted in statistically lower plant growth ( $p<0.01$, ANOVA and post-hoc analysis). By $500^{\circ} \mathrm{C}$, biomass production declined by $>50 \%$ and leaf quality worsened; many samples, particularly clover, showed lowered chlorophyll content (Table 4). At $\geq 750^{\circ} \mathrm{C}$, negligible plant production was observed. 
visibly chlorotic. These changes related well with the loss of nitrogen and the reduced bioavailability of many macro- and micro-nutrients.

217

In Soil 2, fescue's biomass production doubled when the soil was heated to $105^{\circ} \mathrm{C}$ and $250^{\circ} \mathrm{C}$, when compared to the control sample. Heating at $105^{\circ} \mathrm{C}$ released the nitrogen stored in biomass, whereas heating to $250^{\circ} \mathrm{C}$ mineralised nitrogen in organic compounds, both of which were evident by enhanced ammonium levels (Table 2). The plants may have benefited from the release of nitrogen that would otherwise be assimilated in microbial biomass (Kaye and Hart, 1997); improved in plant growth have been noted resulting from some fires (Kennard and Gholz, 2001; Madrigal, et al., 2010). Nitrogen deficiency in the control sample was supported by the significantly lower chlorophyll content in the leaves of the fescue compared to the $105^{\circ} \mathrm{C}$ and $250^{\circ} \mathrm{C}$ treatments (Table 4). A similar pattern in growth and chlorophyll content was not evident for clover in this soil; the presence of numerous nitrogen-fixing root nodules (Table 5) could have provided additional nitrogen to overcome soil deficiency.

For most plant-soil combinations, the $250^{\circ} \mathrm{C}$ heat treatment was statistically intermediate between the $105^{\circ} \mathrm{C}$ and $500^{\circ} \mathrm{C}$ treatments (Fig. 1) in terms of biomass production. In Soil 1, biomass production for clover at $250^{\circ} \mathrm{C}$ is equivalent to production at $500^{\circ} \mathrm{C}$ and lower than expected given biomass production in other soil/plant combinations and reductions in nutrient levels (Table 2). A possible cause was increased toxicity by a chemical released by the heating. This is more pronounced in clover, as it is known to be more sensitive than grasses (Johnson, 1919). The reason for this sensitivity remains unclear, but large increases in ammonium $(+1600 \%)$ and exchangeable manganese $\left(+750 \%\right.$ ) levels (Table 2 ) were apparent at $250^{\circ} \mathrm{C}$ in Soil 1 , both of which are toxic to plants at high levels (Britto and Krunzucker, 2002; Osborne et al., 1981). Similar but less dramatic increases were observed in Soil 2, perhaps explaining why toxicity was not observed in this soil.

\subsection{Microbial Re-colonisation}


Soil samples were subject to DNA extraction and gene quantification using qPCR. No consistent patterns in the data were observed between the various plant and microbe treatments within each heat treatment. Airborne and seedborne re-colonisation supplied a range of organisms to the soil. Airborne colonisation of un-inoculated samples was apparent with visible growth occurring within a few days of re-wetting in the $105^{\circ} \mathrm{C}$ and $250^{\circ} \mathrm{C}$ treatments. This pattern existed for all of the genes quantified and the same functional guilds were present in both inoculated and un-inoculated samples. Because there were no treatment-related differences, results within the plant and microbe treatments were combined to compare temperature-related results with one-way ANOVA.

Levels of 16S-rRNA gene abundance were measured as proxies for overall bacterial abundance.

Eight weeks after re-wetting soils, the bacterial populations were similar $\left(\approx 10^{8}\right.$ genes/g) among the heat treatments $<500^{\circ} \mathrm{C}$ (Fig 2). In these heat treatments, levels of organic matter and nutrients in the soil had not yet significantly declined. The availability of carbon and nutrients, together with the rapid proliferation potential of bacteria, ensured that population levels were fully restored during the period of this experiment.

At $\geq 500^{\circ} \mathrm{C}$, there were fewer bacteria during recovery. The abundance of 16S-rRNA in the soils were two to three order of magnitudes lower in the $500^{\circ} \mathrm{C}, 750^{\circ} \mathrm{C}, 1000^{\circ} \mathrm{C}$ and smouldered samples, which followed organic matter patterns after heat treatments. Quality of organic matter might be important. While organic matter remained at $3-5 \%$ in the soil exposed to $500^{\circ} \mathrm{C}$, there were obvious changes in bacterial abundances. Qualitative changes to the organic matter may have played an important role in microbial proliferation. From the biochar literature, chars produced above 300$400^{\circ} \mathrm{C}$ contained less labile carbon (Rutherford et al., 2012; Song and Guo, 2012) due to increasing levels of complex aromatic compounds as oxygen and hydrogen are lost from organic molecules (Kim et al., 2012). The recalcitrant organic matter likely reduced the soil's capacity for heterotrophic bacteria. Interestingly, in both soils, higher abundances were found in the $1000^{\circ} \mathrm{C}$ heat treatment relative to the $500^{\circ} \mathrm{C}, 750^{\circ} \mathrm{C}$ and smouldered soils, but lower than the air-dried "control" values. 
The abundances of functional genes involved in nitrogen cycling (nirS, nirk, amoA and nifH) followed similar patterns as the 16S-rRNA data (Fig. 2). All of the major guilds responsible for nitrogen cycling were present in the same proportions as 16S rRNA in the different heat treatments with some significant differences. This observation is important, as it suggests that nutrient cycling in the soil could be restored when inputs of limited nutrients are added for any of the heat treatments.

The biggest differences among nirS and nifH abundances were in the smouldered samples. The relative abundances of these genes (as per 16S-rRNA gene values) were quite variable within the smouldered treatments and represent a greater fraction of the microbial community. The reason for the variability remains unclear, but it should be noted that both genes produce enzyme subunits that require non-haeme iron to function. Given the presence of high temperatures and reducing agent (coal tar), changes to iron mineralogy and oxidation state would be likely in smouldered soils.

\subsection{Nodulation and Growth in Clover}

Community development in primary succession must include nitrogen-fixing populations to initiate the cycling of organic nitrogen. Based on the DNA concentrations (Fig 2), nitrogen-fixing genes almost uniformly occurred across all heat treatments, within 1-2 orders of magnitude. However, after heat treatment, successful nodulation was limited to samples that received microbial amendments and relatively high-temperature treatments (Soil 1 at $500-750^{\circ} \mathrm{C}$, and Soil 2 at $500^{\circ} \mathrm{C}$ ) causing soil to become nitrogen limited (Table 5). Even with the potentially successful microbial inoculants present, nodulation was far from universal, which demonstrates the specificity of conditions and microorganisms required; further, the presence of gene DNA does not guarantee that nodulation will occur. Chemical conditions have an effect as well; at lower heat treatments, the excess nitrogen likely inhibited nodulation (e.g., Imsande 1985), as it comes at an energetic cost to the plants. Further, at higher temperature treatments, soils experienced elevated $\mathrm{pH}$ and/or limitation of essential nutrients (e.g., phosphorus) that would limit successful nodulation. 
To determine whether nodulation improved plant growth, samples were grouped by nodule presence; the total biomass production for each plant was compared by t-tests (Fig 3), and statistically higher growth occurred with nodulated plants. Soil 1 heated at $500^{\circ} \mathrm{C}$ showed the lowest growth improvement; however, it also had the lowest numbers of nodules per plant (Table 5). Due to the extreme nitrogen limitation in the $750^{\circ} \mathrm{C}$ sample (Table 2), these samples shows the most dramatic improvement in growth with biomass production increasing four-fold, and for the Soil 2 sample heated at $500^{\circ} \mathrm{C}$, chlorophyll content of the leaves tripled. This further supports the hypothesis that nitrogen limitation caused by soil heating affected plant growth. The leaves of the Soil 1 sample at $750^{\circ} \mathrm{C}$ could not be compared directly to the un-nodulated equivalent due to low biomass production, but chlorophyll content in plants with nodules was triple the value when compared to plants without nodules in the $500^{\circ} \mathrm{C}$ sample for the same soil. Primary organic nitrogen production is critical for the success of restoration strategies (e.g., Vitousek et al. 1989) of thermally remediated sites, particularly if low maintenance and minimal resource input are desired.

\subsection{Microbial activity}

In this study, enzyme assays were used to assess nutrient cycling capability at the end of the growing period to provide an indication of soil recovery. Lower phosphatase activity was observed in Soil 1 compared to Soil 2, particularly for alkali phosphatase due to the lower $\mathrm{pH}$ of Soil 1 ( $\mathrm{pH}=4.7)$ (Fig. 4). Few consistent differences were also observed between plant/microbe treatments though; in some instances, the presence of plants in heated samples enhanced phosphatase activity. For example, in Soil 1 the presence of fescue marginally increased activity in the $105^{\circ} \mathrm{C}$ heat treatments. By far, the most significant effect was phosphatase activity declining with heat treatment, which corroborates previous observations in literature (e.g., Boerner, et al. 2000; Saá, et al., 1993; Serrasolses and Khanna, 1995). This pattern was also evident for the other enzymes tested where exposure at $500^{\circ} \mathrm{C}$ represented a critical point, above which spontaneous microbial recovery in soils will unlikely occur. 
For other enzymes, differences occurred between the soils and the various plant/microbe treatments. $\beta$-glucosidase had the same pattern as the phosphatases in Soil 2. However, in Soil $1, \beta$ glucosidase activity increased in samples heated at $105^{\circ} \mathrm{C}$, which (again) likely attributed to nutrient release during and cell lysis of the microbial community. In addition, the combination of clover with microbial amendment resulted in higher activity, attributable to fungal and bacterial symbiosis in the amendment mixture. Despite elevated heat treatments, increased microbial activity can occur if resultant nutrient conditions become favourable (e.g., Stadden, et al. 1998).

Ammonium oxidase showed consistently different patterns of activity between the two soils tested, with almost no activity being observed in Soil 1 (Fig 4) due to the low $\mathrm{pH}$ of this soil ( $\mathrm{pH}=4.7)$. In Soil 2 , ammonium oxidation was apparent in all of the plant $/$ microbe treatments at $105^{\circ} \mathrm{C}$ with the exception of the treatment without any biological amendment, which displayed no activity other than in the un-heated control. In these samples, the gene-abundance data showed equal proportions of amoA genes. As with clover nodulation, a positive DNA assay does not correlate to activity, rather it suggests that the potential is there; metabolic triggers and other biochemical factors, such as gene expression, must first prevail. These bacteria must have been present on seeds as well as in the microbial inoculants. Further amendments are likely required to fully restore nutrient cycling.

A range of thermal remediation techniques optimised for the vapour extraction of highly volatile organic pollutants operates at relatively low temperatures $\left(40-250^{\circ} \mathrm{C}\right.$; Buettner and Daily, 1995 ; Heron et al., 2009; Robinson et al. 2009); their impacts on soil suitability for plant growth are comparatively minimal. However, given the possibility that either growth enhancement or mild toxicity are possible at these temperatures, pilot studies would be beneficial to determine whether any detrimental effects would impact desired land use. Although spontaneous re-colonisation of 
sites would eventually occur, microbial amendments would be beneficial to enhance community development.

Treatments that rely on higher temperatures $\left(\geq 500^{\circ} \mathrm{C}\right)$ to remove or destroy less volatile compounds, including smouldering (Switzer et al., 2009) and incineration (Anthony and Wang, 2006), create major challenges for re-establishing plant growth and soil ecosystems. Poor to non-existent plant growth, ineffective microbial re-colonisation and deleterious changes to soil physical properties are all obstacles to be overcome (Séré, et al., 2008). Reclamation strategies, such as slow-release nutrient additions (such as compost) provide nutrients for plants and microbial activity, and enhanced water storage and aggregation; however, this could incur purchasing, transportation and spreading costs.

The use of specific combinations of plants and microbes to re-introduce nutrients and organic matter through semi-natural succession (Bradshaw, 1997) would be one economical restoration strategy that could provide a long-term sustainable solution. In this study, red clover improved biological activity in nitrogen deficient soils when the correct bacterial symbionts were simultaneously present to facilitate nitrogen fixation. This could complement, and-or follow the short-term amendment strategy. . Further work to develop the most appropriate combinations for local conditions and remediation conditions will be necessary on a case-by-case basis. Comprehensive biological restoration would provide a longer-term, sustainable solution to site rehabilitation after remediation and reduce the requirements for external inputs into the system.

\section{Conclusions}

This study aimed to understand the linkages between remediation operating temperatures, changes to soil properties and impacts on biological activity. A critical temperature threshold was observed at $500^{\circ} \mathrm{C}$. Treatments operating below this temperature will be amenable to biological recovery and support plant growth, though inoculation with an appropriate microbial community improves the 
recovery of specific biological processes in the soil. Above $500^{\circ} \mathrm{C}$, geochemical changes, most significantly losses of nitrogen and carbon, result in poor plant growth and minimal microbial recolonisation. Such treatments will necessitate more extensive rehabilitation programs that may include the addition of organic amendments or the use of nitrogen fixing assemblages, to reremediation processes it will be possible to ensure that remediated sites offer environmental and economic benefits in addition to lower environmental hazards.

\section{Acknowledgements}

The research was supported by the Department of Civil \& Environmental Engineering and Glasgow Research Research Partnership in Engineering (GRPe). AP was supported by EPSRC Doctoral Training Account at University of Strathclyde. The authors thank Tatayana Peskur for her support with chemical analysis and Andrew Robson for advice about smouldering. Smoldering combustion of liquids is a patented remediation process (e.g. USA 8132987 with others pending, PCT Application PCT/GB2006/004591, priority date 10th December 2005, and PCT/US2012/035248, priority date 29 April 2011).

\section{References}

Abdelmagid, H.M., Tabatabai, M.A., 1987. Nitrate reductase activity of soils. Soil Biol. Biochem., 19,

ADAS, 1985. The Analysis of Agricultural Materials. Agricultural Development and Advisory Service, London, U.K.

Andreu, V., Imeson, A.C., Rubio, J.L., 2001. Temporal changes in soil aggregates and water erosion after a wildfire in a Mediterranean pine forest. Catena, 44, 69-84 soil and oil-contaminated gravel. Fuel, $85,443-450$ 
Queda, A.C., 2008. Evaluation of composts and liming materials in the phytostabilisation of a mine

Arnon, D.I., 1949. Copper enzymes in isolated chloroplasts. Polyphenoloxidase in Beta vulgaris.

Plant Physiol. 24, 1-15

Bárcenas-Moreno, G., Bååth, E., 2009. Bacterial and fungal growth in soil heated at different temperatures to simulate a range of fire intensities. Soil Biol. Biochem. 41, 2517-2526

Bendfeldt, E.S., Burger, J.A., Daniels, W.L., 2001. Quality of amended mine soils after sixteen years. Soil Sci. Soc. Am. J. 65:1736-1744

Boerner, R.E.J., Decker, K.L.M. Sutherland, E.K. 2000. Prescribed burning effects on soil enzyme activity in a souther Ohio hardwood forest: a landscape scale analysis. Soil Biol. Biochem. 32, 899908.

Bradshaw, A., 1997. Restoration of mined lands - using natural processes. Ecol. Eng. 8, 255-269

Britto, D.T., Kronzucker, H.J., 2002. NH4+ toxicity in higher plants: A critical review. J. Plant Physiol. $159,567-584$

BS - British Standards, 1995. BS 7755 Soil Quality, Section 3.8 Determination of organic and total carbon after dry combustion (elementary analysis). BSI Group, London, UK BS - British Standards, 2001. BS EN 13654 Soil improvers and growing media - Determination of nitrogen, Part 2 Dumas method. BSI Group, London, UK higher plants, BSI Group, London, UK 
Bundy, L.G., Meisinger, J.J., 1994. Nitrogen Availability Indices. In : Weaver, R.W, Angle, J.S. and

Bottomley, P.S. (eds.) Methods of Soil Analysis: Part 2-Microbiological and Biochemical

Cébron, A., Beguiristain, T., Faure, P., Norini, M.-P., Masfaraud, J.-F., Leyval, C., 2009. Influence of 6330. microbial bioindicators. Res. Microbiol. 162, 896-907. 606 2011. Effects of soil burn severity on germination and initial establishment of maritime pine seedlings, under greenhouse conditions, in two contrasting experimentally burned soils. Int. J. Wildland Fire. 20: 209-222.

Galang, M.A., Markewitz, D., Morris, L.A., 2010. Soil phosphorus transformations under forest burning and laboratory heat treatments. Geoderma 155, 401-408 related to soil fertility and plant growth. Soil Sci. 149, 344-350 in pristine and impacted prairie streams. Environ. Pollut. 158(10), 3225-3229 
Granged, A.J.P, Zavala, L., Jordan, A., Moreno, G.B., 2011. Post fire evolution of soil properties and vegetation cover in a Mediterranean heathland after experimental burning: A 3-year study. Geoderma 164, 85-94

Gray, D.M., Dighton, J., 2006. Mineralisation of forest litter nutrients by heat and combustion. Soil

Glass, D.W., Johnson, D.W., Blank, R.R., Miller, W.W., 2008. Factors effecting mineral nitrogen

Hargreaves, J.C., Adl, M.S., Warman, P.R., 2008. A review of the use of composted municipal solid

Heron, G., Carroll, S., Nielsen, S.G., 2005. Full-scale removal of DNAPL constituents using steam-

Heron, G., Parker. K., Galligan, J., Holmes, T.C., 2009. Thermal treatment of eight CVOC source zones

Hiscox, J.D., Israelstam, G.F., 1979. A method for the extraction of chlorophyll from leaf tissue without maceration. Can. J. Bot. 57, 1332-1334 Exper. Biol. 37, 348-355. 
Jefferies, R.A., Wilson, K., Bradshaw, A.D., 1981. The potential of legumes as a nitrogen source for the reclamation of derelict land. Plant Soil 59, 173-177 Johnson, J., 1919. The influence of heated soils on seed germination and plant growth. Soil Sci. 7, $1-103$ and nosZ genes of denitrifying bacteria during primary successions of a glacier foreland. Appl. Environ. Microbiol. 72, 5957-5962.

Kang, B.T., Sajjapongse, A., 1980. Effect of heating on properties of some soils from southern Nigeria and growth of rice. Plant Soil 55, 85-95 Kaye, J.P., Hart, S.C., 1997. Competition for nitrogen between plants and microorganisms. Trends Evolut. Ecol. 12, 139-143

Kennard, D.K., Gholz, H.L. 2001. Effects of high- and low-intensity fires on soil properties and plant growth in a Bolivian dry forest. Plant Soil 234, 119-129. by slash and burn fires in Sumatra, Indonesia. Soil Sci. Soc. Amer. J. 64, 1108-1117 Kim, K.H., Kim, J.Y., Cho, T.S., Choi, J.W., 2012. Influence of pyrolysis temperature on physiochemical properties of biochar obtained from the fast pyrolysis of pitch pine (Pinus rigida). Bioresour. Technol. 118, 158-162

Li, R.S., Daniels, W.L., 1992. Nitrogen accumulation and form over time in young mine soils. J.

473 Environ. Qual. 23, 166-172 and morphological traits of 3-year-old Pinus pinaster Ait. Plant Ecol. 208, 279-292 
Monserie, M.-F., Watteau, F., Villemin, G., Ouvrard, S., Morel, J.-L., 2009. Technosol genesis: identification of organo-mineral associations in a young Technosol derived from coking plant waste materials. J. Soils Sed. 9(6), 537-546.

Muyzer, G., de Waal, E.C., Uitterlinden, A.G.,1993. Profiling of complex microbial populations by denaturing gradient gel electrophoresis analysis of polymerase chain reaction-amplified genes coding for 16S rRNA. Appl. Environ. Microbiol. 59, 695-700.

Osborne, G.J., Prately, J.E., Stewart, W.P., 1981. The tolerance of subterranean clover (Trifolium subterraneum I.) to aluminium and manganese. Field Crop Res. 3, 347-358

Pape, A., Knapp, C.W., Switzer, C., 2014. Effects of high temperature remediation processes on soil geochemistry. Environ. Sci. Pollut. Res., In review

Pironi, P., Switzer, C., Rein, G., Fuentes, A., Gerhard, J.I., Torero, J.L., 2009. Small-scale forward smouldering experiments for remediation of coal tar in inert media. Proc. Combust. Inst. 32, 19571964

Poly, F., Ranjard, L., Navaret, S., Gourbière, Monrozier, L.J., 2001. Comparison of nifH gene pools in soils and soil microenvironments with contrasting properties. Appl. Environ. Microbiol. 67, 2255-62. polyaromatic hydrocarbons from contaminated soils using microwave heating. Sep. Purif. Technol. 69, 249-254

Roh, Y., Edwards, N.T., Lee, S.Y., Stiles, C.A., Armes, S., Foss, J.E., 2000. Thermal-treated soil for 

as functional biomarker: molecular fine-scale analysis of natural ammonia-oxidising populations. Appl. Environ. Microbiol. 63, 4700-4712.

503

504

505

506

507

508

509

510

511

512

513

514

515

516

517

Saá, A., Trasar-Cepeda, M.C., Gil-Sotres, F., Carballas, T. 1993. Changes in soil phosphorus and acid phosphatase activity immediately following forest fires. Soil Biol. Biochem. 25, 1223-1230.

Séré, G., Ourvrard, S., Schwartz, C., Renat, J.C., Morel, J.L. 2008. Soil construction: a step for ecological reclamation of derelict lands. J. Soil Sed. 8, 130-136. all obstacles to be overcome.

Serrasolses, I., Khanna, P.K. 1995. Changes in heated and autoclaved forest soils of S.E. Australia. II. Phosphorus and phosphatase activity. Biogeochem. 29, 25-41. Shand, C.A., Williams, B.L., Coutts, G., 2008. Determination of $\mathrm{N}$-species in soil extracts using microplate techniques. Talanta $74,648-654$

Smith, M.S., Yang, R.K., Knapp, C.W., Niu, Y., Peak, N., Hanfelt, M.M., Galland, J.C., Graham, D.W., 2004. Quantification of tetracycline resistance genes in feedlot lagoons by real-time PCR. Appl. Environ. Microbiol. 70, 7372-7377

Song, W., Guo, M., 2012. Quality variations of poultry litter biochar generated at different pyrolysis temperatures. J. Anal. Appl Pyrolysis 94, 138-145

Staddon, W.J., Duchesne, L.C. Trevors, J.T. 1998. Acid phosphatase, alkaline phosphatase and arylsulfatase activities in soils from a jack pine (Pinus banksiana Lamb.) ecosystem after clearcutting, prescribed burning, and scarification. Biol. Fert. Soil 27, 1-4.

Switzer, C., Pironi, P., Gerhard, J.I., Rein, G., Torero, J.L., 2009. Self-sustaining smoldering combustion: A novel remediation process for non-aqueous-phase liquids in porous media. Environ. Sci. Technol. 43, 5871-5877

Switzer, C., Pironi, P., Gerhard, J.I., Rein, G., Torero, J.L., 2014. Volumetric scale-up of smouldering remediation of contaminated materials. J. Haz. Mater. 268, 51-60 
522 Tabatabai, M.A., (1994). Soil Enzymes. In: Weaver, R.W, Angle, J.S., Bottomley, P.S. (eds.) (1994).

523 Methods of Soil Analysis: Part 2 - Microbiological and Biochemical Properties. Soil Science Society

524 of America. Madison, WI, USA

525 Terefe, T., Mariscal-Sancho, I., Peregrina, F., Espejo, R., 2008. Influence of heating on various

526 properties of six Mediterranean soils: a laboratory study. Geoderma 143, 273-280.

527 Thion, C., Cébron, A., Beguiristain, T., Leyval, C., 2012. Long-term in situ dynamics of the fungal 528 communities in a multi-contaminated soil are mainly driven by plants. FEMS Microbiol. Ecol. 82, $529 \quad 169-181$.

530 Ulery, A.L., Graham, R.C., Bowen, L.H., 1996. Forest fire effects on soil phyllosilicates in California. 531 Soil Sci. Soc. Amer. J. 60, 309-315

532 Van Liedekerke, M., Prokop, G., Rabl-Berger, S., Kibblewhite, M., Louwagie, G., 2014. Progress in the 533 management of contaminated sites in Europe. European Commission Joint Research Centre, 534 Institute for Environment and Sustainability. Ispra, Italy

535 Vitousek, P. M., Matson, P.A., Van Cleve, K. 1989. Nitrogen availability and nitrification during 536 succession: primary, secondary and old-field seres. Plant Soil, 115, 229-239. 
Table 1. Primers and reaction conditions for qPCR

\begin{tabular}{|c|c|c|c|c|c|}
\hline Gene & Primers & Melt & Annealing & Elongation & Source \\
\hline 16S-rRNA & $\mathrm{P} 1 / \mathrm{P} 2$ & $15 \mathrm{~s}$ at $95^{\circ} \mathrm{C}$ & $15 \mathrm{~s}$ at $55^{\circ} \mathrm{C}$ & $15 \mathrm{~s}$ at $60^{\circ} \mathrm{C}$ & Muyzer et al., 1993 \\
\hline nifH & PolF/PolR & $10 \mathrm{~s}$ at $95^{\circ} \mathrm{C}$ & $10 \mathrm{~s}$ at $53^{\circ} \mathrm{C}$ & $10 \mathrm{~s}$ at $54^{\circ} \mathrm{C}$ & Poly et al., 2001 \\
\hline nirs & nirSCd3aF/nirSR3cd & $10 \mathrm{~s}$ at $95^{\circ} \mathrm{C}$ & $10 \mathrm{~s}$ at $55^{\circ} \mathrm{C}$ & $10 \mathrm{~s}$ at $60^{\circ} \mathrm{C}$ & Kandeler et al., 2006 \\
\hline nirk & nirK876/nirk1040 & $10 \mathrm{~s}$ at $95^{\circ} \mathrm{C}$ & 10 s at $55^{\circ} \mathrm{C}$ & $10 \mathrm{~s}$ at $60^{\circ} \mathrm{C}$ & Henry et al., 2004 \\
\hline amoA & amoA-1F/amoA-2R & $10 \mathrm{~s}$ at $95^{\circ} \mathrm{C}$ & $10 \mathrm{~s}$ at $52^{\circ} \mathrm{C}$ & $10 \mathrm{~s}$ at $55^{\circ} \mathrm{C}$ & Rotthauwe et al., 1997 \\
\hline
\end{tabular}


Table 2 - Changes to soil chemistry upon heating, mean \pm S.D.

\begin{tabular}{|c|c|c|c|c|c|c|c|c|}
\hline & Treatment & $\mathrm{pH}$ & $\begin{array}{c}\text { E.C. } \\
(\mu S / \mathrm{cm})\end{array}$ & $\begin{array}{c}\text { C.E.C. } \\
\text { (cmolc/kg) }\end{array}$ & $\begin{array}{c}\text { Organic Matter } \\
(\%)\end{array}$ & $\begin{array}{l}\text { Total N } \\
(\mathrm{g} / \mathrm{kg})\end{array}$ & $\begin{array}{c}\text { Inorganic N } \\
(\mathrm{mg} / \mathrm{kg})\end{array}$ & $\begin{array}{c}\text { Organic } P \\
(\mathrm{mg} / \mathrm{kg})\end{array}$ \\
\hline \multirow[t]{7}{*}{ Soil 1} & Air dried & $4.7 \pm 0.0$ & $79 \pm 3$ & $21.9 \pm 2.1$ & $13.6 \pm 0.1$ & $1.02 \pm 0.08$ & $8.3 \pm 0.3$ & $97.5 \pm 4.4$ \\
\hline & $105^{\circ} \mathrm{C}$ & $4.4 \pm 0.1$ & $225 \pm 5$ & $22.2 \pm 0.8$ & $11.7 \pm 0.2$ & $1.15 \pm 0.08$ & $9.0 \pm 0.4$ & $92.7 \pm 1.1$ \\
\hline & $250^{\circ} \mathrm{C}$ & $5.5 \pm 0.1$ & $310 \pm 16$ & $9.8 \pm 0.5$ & $6.9 \pm 0.2$ & $1.16 \pm 0.06$ & $134 \pm 13$ & $85.5 \pm 4.2$ \\
\hline & $500^{\circ} \mathrm{C}$ & $6.2 \pm 0.2$ & $353 \pm 8$ & $3.1 \pm 0.3$ & $2.8 \pm 0.1$ & $0.45 \pm 0.04$ & $7.1 \pm 0.2$ & $39.0 \pm 2.7$ \\
\hline & $750^{\circ} \mathrm{C}$ & $6.4 \pm 0.2$ & $286 \pm 15$ & $1.0 \pm 0.1$ & $0.6 \pm 0.1$ & $0.14 \pm 0.01$ & n.d. & $36.4 \pm 2.3$ \\
\hline & $1000^{\circ} \mathrm{C}$ & $7.3 \pm 0.1$ & $55 \pm 2$ & $0.4 \pm 0.3$ & $0.2 \pm 0.1$ & $0.01 \pm 0.00$ & n.d. & $3.0 \pm 0.3$ \\
\hline & Smoulder & $7.5 \pm 0.22$ & $120 \pm 1313$ & $0.5 \pm 0.22$ & $0.3 \pm 0.0$ & $0.08 \pm 0.01$ & n.d. & $22.1 \pm 5.5$ \\
\hline \multirow[t]{8}{*}{ Soil 2} & Air dried & $7.4 \pm 0.0$ & $732 \pm 16$ & $28.2 \pm 4.6$ & $17.3 \pm 0.3$ & $1.00 \pm 0.10$ & $6.0 \pm 0.8$ & $94.0 \pm 10.6$ \\
\hline & $105^{\circ} \mathrm{C}$ & $7.1 \pm 0.0$ & $978 \pm 64$ & $16.0 \pm 3.2$ & $16.5 \pm 1.0$ & $1.15 \pm 0.08$ & $11.4 \pm 0.4$ & $103.9 \pm 4.4$ \\
\hline & $250^{\circ} \mathrm{C}$ & $7.3 \pm 0.1$ & $1490 \pm 80$ & $14.2 \pm 3.7$ & $11.6 \pm 0.3$ & $0.92 \pm 0.07$ & $23.7 \pm 1.3$ & $114.0 \pm 7.1$ \\
\hline & $500^{\circ} \mathrm{C}$ & $9.0 \pm 0.0$ & $948 \pm 39$ & $6.3 \pm 0.9$ & $5.1 \pm 0.1$ & $0.62 \pm 0.10$ & $6.9 \pm 1.5$ & $125.2 \pm 9.5$ \\
\hline & $750^{\circ} \mathrm{C}$ & $11.3 \pm 0.0$ & $1240 \pm 10$ & $2.2 \pm 0.7$ & $1.9 \pm 0.1$ & $0.25 \pm 0.04$ & n.d. & $51.8 \pm 0.9$ \\
\hline & $1000^{\circ} \mathrm{C}$ & $11.4 \pm 0.1$ & $1410 \pm 150$ & $0.6 \pm 0.2$ & $0.0 \pm 0.0$ & $0.02 \pm 0.00$ & n.d. & $22.0 \pm 0.9$ \\
\hline & Smoulder & $11.7 \pm 0.22$ & $1783 \pm 3737$ & $0.8 \pm 0.3$ & $0.2 \pm 0.1$ & $0.10 \pm 0.00$ & n.d. & $44.9 \pm 8.4$ \\
\hline & Treatment & $\begin{array}{l}\text { Exch. Ca } \\
(\mathrm{mg} / \mathrm{kg})\end{array}$ & $\begin{array}{l}\text { Exch. Mg } \\
(\mathrm{mg} / \mathrm{kg})\end{array}$ & $\begin{array}{l}\text { Exch. K } \\
(\mathrm{mg} / \mathrm{kg})\end{array}$ & $\begin{array}{l}\text { Exch. Na } \\
(\mathrm{mg} / \mathrm{kg})\end{array}$ & $\begin{array}{l}\text { Exch. Mn } \\
(\mathrm{mg} / \mathrm{kg})\end{array}$ & $\begin{array}{l}\text { Avail. Cu } \\
(\mathrm{mg} / \mathrm{kg})\end{array}$ & $\begin{array}{l}\text { Avail. Zn } \\
\text { (mg/kg) }\end{array}$ \\
\hline \multirow[t]{7}{*}{ Soil 1} & Air dried & $1290 \pm 60$ & $109 \pm 3$ & $114 \pm 3$ & $127 \pm 13$ & $4.3 \pm 0.3$ & $6.9 \pm 0.3$ & $21.0 \pm 1.2$ \\
\hline & $105^{\circ} \mathrm{C}$ & $1350 \pm 40$ & $101 \pm 5$ & $89 \pm 9$ & $142 \pm 32$ & $10.2 \pm 0.9$ & $6.8 \pm 0.6$ & $19.3 \pm 0.8$ \\
\hline & $250^{\circ} \mathrm{C}$ & $857 \pm 52$ & $63 \pm 3$ & $88 \pm 10$ & $138 \pm 8$ & $32.4 \pm 5.7$ & $4.2 \pm 0.2$ & $16.6 \pm 1.1$ \\
\hline & $500^{\circ} \mathrm{C}$ & $569 \pm 5$ & $81 \pm 2$ & $196 \pm 9$ & $123 \pm 8$ & $10.8 \pm 2.2$ & $2.3 \pm 0.1$ & $5.1 \pm 0.3$ \\
\hline & $750^{\circ} \mathrm{C}$ & $341 \pm 39$ & $2 \pm 0$ & $153 \pm 5$ & $156 \pm 14$ & $5.5 \pm 1.2$ & $0.9 \pm 0.0$ & $1.1 \pm 0.1$ \\
\hline & $1000^{\circ} \mathrm{C}$ & $88 \pm 4$ & $0 \pm 0$ & $34 \pm 1$ & $130 \pm 4$ & $1.5 \pm 0.1$ & $0.1 \pm 0.0$ & $0.3 \pm 0.2$ \\
\hline & Smoulder & $254 \pm 28$ & $48 \pm 10$ & $86 \pm 3$ & $124 \pm 55$ & $1.7 \pm 0.2$ & $0.6 \pm 0.1$ & $0.7 \pm 0.2$ \\
\hline \multirow[t]{7}{*}{ Soil 2} & Air dried & $4060 \pm 680$ & $368 \pm 22$ & $983 \pm 83$ & $241 \pm 10$ & n.d. & $6.1 \pm 0.5$ & $18.6 \pm 0.6$ \\
\hline & $105^{\circ} \mathrm{C}$ & $2780 \pm 890$ & $284 \pm 39$ & $806 \pm 121$ & $276 \pm 12$ & n.d. & $6.2 \pm 0.8$ & $21.6 \pm 3.0$ \\
\hline & $250^{\circ} \mathrm{C}$ & $1810 \pm 580$ & $144 \pm 29$ & $568 \pm 49$ & $281 \pm 6$ & $13.8 \pm 3.9$ & $4.6 \pm 0.1$ & $19.4 \pm 0.7$ \\
\hline & $500^{\circ} \mathrm{C}$ & $2140 \pm 300$ & $127 \pm 11$ & $400 \pm 8$ & $251 \pm 30$ & $6.3 \pm 1.2$ & $1.8 \pm 0.2$ & $5.7 \pm 0.3$ \\
\hline & $750^{\circ} \mathrm{C}$ & $3680 \pm 200$ & $266 \pm 9$ & $160 \pm 12$ & $249 \pm 4$ & $3.5 \pm 0.7$ & $1.7 \pm 0.1$ & $2.2 \pm 0.2$ \\
\hline & $1000^{\circ} \mathrm{C}$ & $2150 \pm 250$ & $55 \pm 4$ & $55 \pm 4$ & $268 \pm 15$ & n.d. & $0.5 \pm 0.0$ & $0.8 \pm 0.1$ \\
\hline & Smoulder & $3460 \pm 880$ & $106 \pm 38$ & $86 \pm 7$ & $210 \pm 12$ & n.d. & $1.2 \pm 0.2$ & $1.9 \pm 0.3$ \\
\hline
\end{tabular}


Table 3 - Changes to particle size distribution upon heating, mean \pm S.D.

\begin{tabular}{rcccccc}
\hline & & Soil 1 & & & Soil 2 & \\
Treatment & Sand (\%) & Silt (\%) & Clay (\%) & Sand (\%) & Silt (\%) & Clay (\%) \\
\hline Air dried & $37.9 \pm 2.5$ & $48.4 \pm 2.0$ & $13.7 \pm 0.5$ & $70.9 \pm 1.1$ & $19.2 \pm 1.3$ & $9.9 \pm 0.3$ \\
$105^{\circ} \mathrm{C}$ & $40.5 \pm 2.2$ & $46.1 \pm 2.7$ & $13.4 \pm 1.1$ & $72.2 \pm 0.9$ & $18.1 \pm 1.0$ & $9.8 \pm 0.2$ \\
$250^{\circ} \mathrm{C}$ & $38.4 \pm 2.1$ & $49.9 \pm 1.4$ & $11.7 \pm 0.7$ & $71.1 \pm 2.4$ & $20.2 \pm 2.2$ & $8.7 \pm 0.4$ \\
$500^{\circ} \mathrm{C}$ & $43.7 \pm 2.6$ & $51.7 \pm 2.4$ & $4.7 \pm 0.2$ & $86.9 \pm 1.3$ & $10.9 \pm 1.2$ & $2.2 \pm 0.1$ \\
$750^{\circ} \mathrm{C}$ & $53.0 \pm 0.5$ & $45.5 \pm 0.7$ & $1.6 \pm 0.2$ & $89.7 \pm 0.9$ & $8.3 \pm 1.2$ & $1.9 \pm 0.3$ \\
$1000^{\circ} \mathrm{C}$ & $85.5 \pm 2.1$ & $14.5 \pm 2.1$ & $0.0 \pm 0.1$ & $90.3 \pm 0.3$ & $7.2 \pm 0.3$ & $2.5 \pm 0.1$ \\
Smoulder & $75.3 \pm 1.3$ & $23.6 \pm 1.9$ & $1.1 \pm 0.6$ & $96.3 \pm 0.7$ & $2.2 \pm 0.6$ & $1.5 \pm 0.3$ \\
\hline
\end{tabular}


Table 4 - Leaf chlorophyll content (mg/g dry mass) for soils inoculated with sterile water (control) and aerated compost tea (M.A.). Values were not determined (n.d.) where biomass was too small for analysis. \pm S.D.

\begin{tabular}{|c|c|c|c|c|c|c|c|c|}
\hline \multirow[b]{3}{*}{ Treatment } & \multicolumn{4}{|c|}{ Soil 1} & \multicolumn{4}{|c|}{ Soil 2} \\
\hline & \multicolumn{2}{|c|}{ Clover } & \multicolumn{2}{|c|}{ Fescue } & \multicolumn{2}{|c|}{ Clover } & \multicolumn{2}{|c|}{ Fescue } \\
\hline & Control & M.A. & Control & M.A. & Control & M.A. & Control & M.A. \\
\hline Air dried & $20.9 \pm 2.2$ & $20.1 \pm 0.9$ & $15.2 \pm 2.7$ & $16.1 \pm 2.5$ & $27.5 \pm 1.8$ & $27.0 \pm 1.2$ & $9.7 \pm 1.6$ & $11.1 \pm 0.3$ \\
\hline $105^{\circ} \mathrm{C}$ & $22.0 \pm 1.2$ & $23.4 \pm 1.2$ & $20.6 \pm 1.7$ & $17.9 \pm 2.3$ & $19.2 \pm 5.3$ & $19.9 \pm 5.9$ & $20.9 \pm 2.8$ & $19.4 \pm 3.0$ \\
\hline $250^{\circ} \mathrm{C}$ & $25.1 \pm 1.2$ & $21.9 \pm 2.9$ & $17.7 \pm 1.1$ & $19.2 \pm 0.4$ & $19.0 \pm 2.9$ & $26.7 \pm 3.7$ & $18.7 \pm 1.2$ & $18.7 \pm 1.6$ \\
\hline $500^{\circ} \mathrm{C}$ & $5.8 \pm 1.8$ & $7.5 \pm 1.7$ & $14.3 \pm 1.3$ & $14.2 \pm 0.9$ & $4.8 \pm 1.2$ & $16.9 \pm 4.0$ & $12.2 \pm 0.8$ & $15.8 \pm 2.6$ \\
\hline $750^{\circ} \mathrm{C}$ & n.d. & $18.5 \pm 1.2$ & n.d. & n.d. & n.d. & n.d. & n.d. & n.d. \\
\hline $1000^{\circ} \mathrm{C}$ & n.d. & n.d. & n.d. & n.d. & n.d. & n.d. & n.d. & n.d. \\
\hline Smoulder & n.d. & n.d. & n.d. & n.d. & n.d. & n.d. & n.d. & n.d. \\
\hline
\end{tabular}


Table 5 - Root nodulation of clover in soils with microbial amendment (M.A.) and without (control), \pm S.D.

\begin{tabular}{|c|c|c|c|c|}
\hline \multirow[b]{2}{*}{ Treatment } & \multicolumn{2}{|c|}{ Soil 1} & \multicolumn{2}{|c|}{ Soil 2} \\
\hline & Control & M.A. & Control & M.A. \\
\hline Air dried & $24 \pm 9$ & $20 \pm 6$ & $32 \pm 4$ & $23 \pm 8$ \\
\hline 105 & $0 \pm 0$ & $0 \pm 0$ & $0 \pm 0$ & $37 \pm 17$ \\
\hline 250 & $0 \pm 0$ & $0 \pm 0$ & $0 \pm 0$ & $0 \pm 0$ \\
\hline 500 & $0 \pm 0$ & $8 \pm 7$ & $0 \pm 0$ & $14 \pm 7$ \\
\hline 750 & $0 \pm 0$ & $17 \pm 19$ & $0 \pm 0$ & $0 \pm 0$ \\
\hline 1000 & $0 \pm 0$ & $0 \pm 0$ & $0 \pm 0$ & $0 \pm 0$ \\
\hline
\end{tabular}


Figure captions:

Figure 1. Above and below ground extension and biomass for Red Clover and Red Fescue grown in air dried, heated and smouldered (SM) samples of two soils. Error bars represent one standard deviation and letters denote statistically significant differences in each series.

Figure 2. DNA quantification in heated soils eight weeks after inoculation. Error bars represent one S.D. and letters denote statistically different groupings

Figure 3 - Total biomass for clover separated by nodulation in heated samples were successful nodulation occurred. P-values are reported for t-tests.

Figure 4. Enzyme activity eight weeks after the inoculation of heated soils with sterile water or aerated compost tea (MA). Error bars represent one standard deviation. 